

\title{
SOLIDIFICATION/STABLIZATION OF TECHNETIUM IN CEMENT-BASED GROUTS
}

\author{
T. Michael Gilliam, Wiliam D. Bostick 2 \\ Roger D. Spence', and J. L. Shoemaker ${ }^{2}$
}

\section{ABSTRACT}

Mixed low-level radioactive and chemically hazardous process treatment wastes from the Pcrtsmouth Gaseous Diffusion Plant are stabilized by solidification in cement-based grouts.

Conventional portland cement and ty ash grouts have been shown to be effective for retention of hydrolyzable metals (e.g. lead, cadmium, uranium and nickel) but are marginally acceptable for retention of radioactive Tc-99, which is present in the waste as the highly mobile pertechnate anion. Addition of ground blast furnace slag to the grout is shown to reduce the leachability of technetium by several orders of magnitude. The selective effect of slag is believed to be due to its ability to reduce Tc(VII) to the less soluble Tc(IV) species.

\section{INTRODUCTION}

Solidification/Stabilization techniques using cement-based grouts are the most widely used technology for the treatment and ultimate disposal of both radioactive and chemically hazardous waste because of their low processing costs, compatibility with a wide variety of disposal scenarios, and ability to meet stringent processing and performance requirements. Grouts, which meet all applicable regulatory requirements for the disposal of heavy metals (1), selected organics (2), and radionuclides (3), have been developed. In general, the performance of these grouts in sequestering the waste constituents of concem is most successful when the constituent of interest is relatively insoluble in the high $\mathrm{pH}$ of the grout pore water. Grouts, particularly neat cement-paste grouts, have proven less successful in sequestering species such as technetium and nitrates, which are readily soluble in pore water.

Technetium is one of four radionuclides (Tc-99, H-3, C-14, and I-131) of particular concern to the U.S. Nuclear Regulatory Commission (NRC) because of their mobility and biological activity (4). The mobility of technetium results in large part from the movement of the pertechnate anion Iprevalent in low-level radioactive waste (LLW)] through soil and geologic strata with little or no interaction with

${ }^{1}$ Oak Ridge National Laboratory, Post Office Box 2003, Oak Ridge, Tennessee 37831-7273

Oak Ridge Gaseous Diffusion Plant, Post Office Box 2003, Oak Ridge, Tennessee 37831-7272 
the surrounding matrix. Ground blast furnace slag has been shown to improve the leach resistance of cement-based waste forms, particularly in regard to technetium $(5,6)$. This improved performance has been attributed to iewer and srialler pores in the solidified slags (versus a neat cement paste) and to the reduction of the pertechnate ion to a less soluble form.

This paper presents preliminary results of a grout development effort to identify grout formulas that can satisfactorily sequester Tc-99 contained in an existing Portsmouth Gaseous Diffusion Plant waste.

\section{WASTE CHARACTERIZATION}

The LLW examined in this study originates from the treatment of an aqueous effluent or "raffinate" from uranium recovery and equipment decontamination operations at the Portsmouth Gaseous Diffusion Plant in Portsmouth, Ohio. The acidic raffinate is diluted and the $\mathrm{pH}$ adjusted to a value of 8.2 to 8.5 . The $\mathrm{pH}$ adjustment resuls in the precipitation of metal hydroxides, which are further coccentrated by paper filtration to yield a filter cake designated as heavy metals sludge (HMS) and a HMS filtrate. Although the sludge is basically a soft solid, it contains a significant amount of liquid ( $\sim 65$ wt\%). It has also been shown to be characteristically hazardous according to the EP-Toxicity test $(7,8)$ for both cadmium and lead and, hence, is a mixed waste. Typical concentrations of selected constituents for both the sludge and filtrate are shown in Table 1. The high concentrations of technetium and nitrate remaining in the sludge filter cake is due primarily to incomplete dewatering.

\section{DRY-SOLIDS BLEND COMPONENTS}

Dry-solids blend components of the grouts tested were: (a) Type I-II LA Portland Cement obtained from the Dixie Cement Company in Knoxville, Tennessee; (b) ASTM Class F fly ash from Centralia, Washington, obtained from Pozzolanic International in Mercer Island, Washington; and (c) granulated blast furnace slag (BFS). Blast furnace slag is produced when the molten slag from a blast furnace is cooled quickly to minimize crystallization and is a blend of amorphous silicates and aluminosilicates of calcium and other bases. Because of the presence of ferrous iron and reduced sulfur 
compounds, BFSs may impart a selective retention for mobile species such as $\mathrm{Tc}$ (VII) by reduction to a less soluble valence state such as Tc(IV). Four sources of BFS were evaluated: (I) a material originating from Japan and obtained from Ash Grove Cement West Inc., in Kennewick, Washington; (II) a material originating from Cleveland Republic Furnace No. 6 and obtained from Standard Slag Company in Canfield, Ohio; (III) the Cleveland slag with gypsum added ar 3 wt\%; and (IV) material originating from Sparrow's Point, Maryland, obtained from Blue Circle Atlantic, Inc., in Atlanta, Georgia.

\section{TEST AND SAMPLE PREPARATION PROCEDURES}

The dry-solids blend components for each grout formula were placed in a V-blender and tumbled for $4 \mathrm{~h}$. The resulting blend was added to the waste over a $30 \mathrm{~s}$ period in a Model N-50 Hobart mixer, which was set a low stirring rate $(\sim 139 \mathrm{rpm})$. the stirring speed was then increased to a medium setting ( $\sim 285 \mathrm{rpm})$ and allowed to mix for an additional $30 \mathrm{~s}$. The resulting freshly prepared grouts were then poured into sylindrical teflon molds $(2.55-\mathrm{cm}$ diam by $4.80-\mathrm{cm}$ length) and allowed to cure at $100 \%$ humidity for $28 \mathrm{~d}$ (9). The resulting monolithic samples were then leached following the abbreviated ANSVANS-16.1-1986 leaching procedure (10). This procedure produces a figure of merit designated as a leachability index (LI), which can be used to compare the leach resistance of different grout formulas. This leachability index is the basis for comparison of performance for the formulas tested in this preliminary study. It should be noted that unless otherwise specified, all indices reported in this paper are the average obtained from three replicate samples.

\section{EFFECT OF SLAG SOURCE}

A single right circular cylindrical sample (3.3-cm diam by $7.1-\mathrm{cm}$ length) was prepared with HMS using a reference grout formula used at the Oak Ridge Gaseous Diffusion Plant (ORGDP) Concrete Fixation Facility for stabilization of waste treatment pond sludges. The grout matrix composition in wi\% was 38.3\% HMS, $11.7 \%$ added water (for a total water content of 35.5\%), 25.0\% Type I-II-LA Portland cement, and 25.0\% ASTM Class F fly ash. A commercially available (Master Builders, Cleveland, Ohio) 
air entrainment admixture, MB-AE-10, was auded to the dry-solids blend at 0.12 wt\%. This admixture is used at the ORGDP Concrete Fixation Facility to improve processibility for large batch pours.

An EP-Toxicity test was performed on the sample, and, as expected, the grout rendered the waste nonhazardous as per this characteristic. The resulting leachate concentrations of all of the eight metals addressed in this test (As, $\mathrm{Ba}, \mathrm{Cd}, \mathrm{Cr}, \mathrm{Pb}, \mathrm{Hg}$, Se, and $\mathrm{Ag}$ ) were below $\mathrm{U}$. S. Environmental Protection Agency (EPA) primary drinking water standards with the possible exception of total $\mathrm{Cr}, \mathrm{Pb}$, and Ag, which were $<0.1,<0.5$, and $<0.06 \mathrm{ppm}$, respectively. An ANSLANS-16.1-1986 leach test performed on this sample yielded leachability indices for Tc-99 and nitrate of 6.1 and 5.5, respectively.

This test verified that in a regulatory context, the metals were not of major concern to this study. Furthermore, this test allowed the visual observation that waste constituents, particularly, lead, had no deleterious affects on the rate of set of the grout. Thus, the development effort could concentrate on improving the retention of technetium and nitrates using a surrogate to minimize nonhomogeneity concerns for the small sample size used.

Using HMS filtrate as a surrogate, ANSUANS-16.1-1986 samples were prepared with the following composition: 40 wt\% HMS filtrate, 20 wt\% BFS, 20 w!\% ASTM Class F fly ash, and 20 wt\% Type I-II LA Portland cement. Four sources of BFS were tested, and their resulting leachability indices are shown in Table 2. An additional test was performed on the formula containing BFS from Japan by adding an air entrainment admixture that is used routinely at the ORGDP Concrete Fixation Facility.

The data in Table 2 clearly show the improved retention of Tc-99 over the reference ORGDP formula by 4.4 units (10.5 versus 6.1) as measured by the leachability index Nitrate retention was also improved, although only by 1.4 units (7.3 versus 5.9$)$. It should be noted that, assuming diffusion controlled release, an increase in leachability index of one unit corresponds to a reduction in the effective diffusion coefficient by a factor of 10 . In addition, the indices for the various formulas tested are quite similar, averaging $10.5 \pm 0.5$ for Tc-99 and $7.3 \pm 0.1$ for nitrate, indicating both the source of the BFS and the use of the admixture do not measurably change the retention performance for technetium and nitrate. 


\section{EFFECT OF SELECTED ADDITIVES}

In a companion study several additives (iron metal, ferrous sulfide and ferrous sulfate) were found to be effective in the removal of Tc-99 and heavy metals from the HMS filtrate (11). The effects of two of these additives on the grout matrix containing HMS were studied. It should be noted that the comparisons discussed in this section were from single samples.

Iron filings ( -40 mesh) were added to a simple cement/fly ash blend and the leachability index was determined. As shown in Table 3, the leachability index obtained from a grout containing trace arnounts of iron filings (B-174-1) increased only slightly from that exhibited by the cement/fly ash grout (B-174-2).

The addition of FeSO4 to the simple cement/fly asta grout (1361-162-4) had a more positive effect. As shown in Table 3, the leachability index increased from 7.7 to 9.3.

\section{EFFECT OF SOLUBLE SULFIDE ION}

The work of Angus and Glasser (12) suggests that the addition of about $4.5 \times 10^{-1}$ mol $\mathrm{Na}_{2} \mathrm{~S}$ per gram of cement produced a cement paste with pore water redox potential (Eh) comparable with that of a grout paste prepared with BFS. In Table 4 the effect of technical-grade sodium sulfide $\left(\mathrm{Na}_{2} \mathrm{~S} \cdot 9 \mathrm{H}_{2} \mathrm{O}\right.$, $-80 \%$ pure) as an additive to grout dry-solids blend is shown. The reductive soluble sulfide (added to about $6 \times 10^{-5}$ mol s$)^{-2}$ per gram of dry-solids blend) is observed to significantly improve retention of Tc99 as evidenced by the increase in leachability index.

\section{DISCUSSION}

The results presented indicate that the source of granulated BFS does not measurably effect retention of technetium and nitrate for the four tested. Indeed, the slag characteristics were similar with gross chemical composition generally falling within industry averages as reported in brochures from the National Slag Association (8). Bulk densities of the slags ranged from 2.85 to $2.96 \mathrm{~g} / \mathrm{cm}^{2}$, and surface area measurements [calculated from nitrogen adsorption measurements and Brunauer-Emmett-Teller 
Theory (BET)] ranged from 1.80 to $2.4 \mathrm{~m}^{2} / \mathrm{g}$. It should be noted that the BFS from Japan (as received) contained 1 wt\% gypsum added as a grinding agent. Thus, it can be concluded that for this application, the source of BFS is driven by economics rather that performance.

The results presented also clearly demonstrate the improved retention of technetium and , to a lesser extent, nitrates by the addition of granulated BFS. As stated earlier, this improvement has been attributed to the reduction potential of the slag and to the resulting less porous grout product. To assess the redox potential of the slags, Eh was measured on aqueous samples of the grout matrix materials, prepared by adding $5 \mathrm{~g}$ of each matrix material to $10 \mathrm{~mL}$ of $0.1 \mathrm{~N} \mathrm{NaOH}$ and shaken overnight before Eh measurement. Relative Eh values for the slags were approximately $-250 \mathrm{mV}$ compared to approximately $450 \mathrm{mV}$ for fly ash and cement.

It can be hypothesized that porosity reduction and tortuosity increase in the grout matrix can be qualitatively observed by the leachability index for nitrate. As nitrates are readily soluble in grout pore water, any significant improvement in its retention may be attributed to these factors. As shown in Table 2, the use of granulated BFS improved nitrate retention but by a relatively small amount compared with technetium. Thus, it can be concluded that the principal mechanism of improved retention is a result of the redox potential of the BFS and not the resulting improver physical properties of the grout.

As shown in Table 4, the effectiveness of BFS may be due to the presence of readily soluble sulfide compounds. Although trace additions of iron filings and FeSO4 (Table 3) did not significantly improve the retention of Tc-99, neither did they have deleterious effects on its retention. Thus, trace additives can be used as a pretreatment step to reduce and precipitate the Tc-99 (thereby reducing the volume for disposal) and then can be incorporated into a grout with no reduction in observed leach behavior.

Although this paper focuses on Tc-99, the results are believed to be applicable to other constituents which are $\mathrm{pH}$ sensitive. $\mathrm{Cr}$, with its highly mobile form $\mathrm{Cr}(\mathrm{VI})$, is a prime candidate for treatment and stabilization using granulated BFS. 


\section{ACKNOWLEDGEMENT}

This research was sponsored by the Enrichment Technology Programs and Office of Defense,

Waste, and Transportation Management, U.S. Department of Energy, under Contract DE-AC05840R21400 with Martin Marietta Energy Systems, Inc. 


\section{REFERENCES}

1. Gilliam, T. M., Leach Testing of Hydrofracture Grouts Containing Hazardous Waste. Journal of the Underground Injection Practices Council, 1, 192, 1986.

2. Gilliam, T. Michael, Dole, Leslie R., and McDaniel, Earl W., Waste Immobilization in Cementbased Grouts. Hazardous and Industrial Solid Waste Testing and Disposal: ASTM Special Technical Publication 933, 6, 295, 1986.

3. Sams, T. L., McDaniel, E W., and Gilliam, T. M., Immobilization of Neutralized CladdingRemoval Waste in a Cement-based Grout. In: Proceeding of the Second International Conference on Radioactive Waste Management, ISBN: 0-919784-0809, Canadian Nuclear Society, Sept. 7-11, 1986.

4. 10 CFR 20, U. S. Nuclear Regulatory Commission, Standards for Protection Against Radiation, Federal Register, Vol 47, No 248, December 27, 1982.

5. Tallent, O. K., McDaniel, E. W., Del Tyl, G. D., Dodson, K. E., and Trotter, D. R., Immobilization of Technetium and Nitrate in Cement-based Materials. Paper presented at Materials Research Society Symposium, November 30 - December 3, 1987, Boston, Massachusetts.

6. Malek, R. L. A., Roy, D. M., Barnes, M. W., and Langton, C. A., Slag-Cement - Low Level Waste Forms at the Savannah River Plant. DP-MS-85-9, Savannah River Laboratory, Aiken, South Carolina, 1985.

7. Hall, R. M., Watson, T., Davidson, J. J., Case, D. R., and Bryson, N. S., RCRA Hazardous Wastes Handbook, 6 ed, Government Institutes, Inc., Rockwell, MD, 1985.

8. Bostick, W. D., Shoemaker, J. L., Fellows, R. L., Spence, R. D., Gilliam, T. M., McDaniel, E. W., and Evans-Brown, B. S., Blast Furnace Slag-Cement Blends for Immobilization of Technetium-Containing Wastes. K/QT-203, Oak Ridge Gaseous Diffusion Plant, Oak Ridge, Tennessee, 1988.

9. Gilliam, T. M. and Loflin, J. A., Leachability Studies of Hydrofracture Grouts. ORNL/TM-9879, Oak Ridge National Laboratory, Oak Ridge, Tennessee, 1986.

10. ANSI/ANS-16.1-1986, Measurement of the Leachability of Solidified Low-Level Radioactive Wastes by a Short-Term Test Procedure, American Nuclear Society, La Grange Park, IL., 1986.

11. Bostick, W. D. and Evans-Brown, B. S., Sorptive Removal of Technetium from Heavy Metals, Sludge Filtrate Containing Nitrate Ion. K/QT-160, Oak Ridge Gaseous Diffusion Plant, Oak Ridge, Tennessee, 1988.

12. Angus, J. J. and Glasser, F. P., The Chemical Environment in Cement Matrices. In: Materials Research Society Symposium proceedings, 50, 547, 1986. 
Table 1. Characterization of heavy metal sludge and filtrates

Constituent

Sludge

Concentration $(\mathrm{ug} / \mathrm{g})$
Filtrate

Concentration

$(\mathrm{mg} / \mathrm{L})$
Arsenic

Barium

Cadium

Chromium

Lead

Mercury

Selenium

Silver

Aluminum

Copper

Iron

Nickel

Uranium

Zinc

Vitrate

Technetium
4.5

35.

970.

490.

52,300 .

$<1$.

$<0.5$

5.7

96,000 .

1,900 .

36,000 .

6,000 .

310.

1,300 .

117,000 .

5.13
0.47

$<0.03$

$<0.1$

$<0.5$

0.92

$<0.06$

8.5

$<0.04$

$<0.04$

$<0.1$

$<0.3$

$<0.01$
94,000 .

13.7 
Table 2. Leachability indices for technetium and nitrate from grouts containing granulated BFS

Slag source

Leachability

${ }^{90} \mathrm{Tc}$

Index $\mathbf{N O}_{3}$

Cleveland

$11.12 \pm 0.33$

$7.40 \pm 0.21$

Japan

$9.99 \pm 0.62$

$7.22 \pm 0.03$

Japan

$10.45 \pm 0.44$

$7.43 \pm 0.15$

Cleveland $^{b}$

$10.97 \pm 0.25$

$7.23 \pm 0.13$

Cleveland

$9.91 \pm 0.16$

$7.19 \pm 0.03$

Sparrow Point

$10.41 \pm 0.17$

$7.23 \pm 0.18$

AVERAGE

$10.50 \pm 0.50$

$7.30 \pm 0.10$

MB-AE-10 added to final dry-solids blend at 0.12 wt \%.

${ }^{b}$ Gypsum added to slag at 3 wt \%. 
Table 3. Stabilization of HMS in grout: effect of miscellaneous additives

B-174-3 B-174-4 1361-162-4

Constituent added to

as-poured we: grout, wr\%

\section{Raw HMS*}

As total

13.9

13.9

13.9

As solids

4.5

4.5

4.5

Water

As diluent

As total ${ }^{\mathrm{b}}$

36.1

45.5

36.1

45.5

36.1

45.5

Portland cement

Type I-II LA

23.2

25.0

24.0

Fly ash, ASTM Class F

23.2

25.0

24.0

Other Additives

Iron fillings

( -40 mesh)

3.7

$\mathrm{FeSO}_{4}$

2.0

ANSL/ANS-16.1-1986 Leachability index

Tc-99

8.1

7.7

9.3

${ }^{3}$ Raw HMS contains 32.6 wt \% solids and 67.4 wt \% water

'Total water is the sum of that added as diluent and from sludge

'Samples were cured for $30 \mathrm{~d}$ prior to leach test 
Table 4. Leach performance of HMS in ordinary portland cement-fly ash grouts: effect of added sodium sulfide

Blend designation

\begin{tabular}{llll}
\hline KS & $\mathrm{KS}+\mathrm{S}$ & $\mathrm{MH}$ & $\mathrm{MH}+\mathrm{S}$
\end{tabular}

Constituent added to

as-poured grout, wt \%

Raw HMS:"

As total

As solids

Water

As diluent

As total

Portland cement

(Type I-II)

Fly ash

(Class F)

Sodium sulfide

(technical) $^{c}$
30.0

9.8

30.0

9.8

13.9

4.5

13.9

4.5
20.0

40.2

25.0

25.0

24.6

25.0

36.1

45.5

25.0

24.6

0.9
24.6

36.1

45.5

24.6

0.9

\section{ANS-16.1 leachability \\ index (30-day cure)}

Tc-99

$6.8 \pm 0.3$

$9.4 \pm 0.1$

$7.2 \pm 0.2$

$10.0 \pm 0.5$

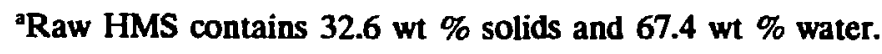

'Total water is the sum of that added from the sludge and diluent.

Technical grade sodium sulfide $\left(\mathrm{NaS} \cdot 9 \mathrm{H}_{2} \mathrm{O},-80 \%\right.$ pure, from PPG Industries, Pittsburgh, PA 15272 , about $\$ 130$ per $400 \mathrm{lb}$ in 1987 ). 